\title{
PENGARUH PROGRAM GREEN MARKETING TERHADAP KEPUTUSAN PEMBELIAN OLEH GENERASI MILLENIAL (Studi Kasus Pada Produk Indomilk)
}

\author{
Khurotul Aeni Widya Pratidhina ${ }^{1}$ Imanuddin Hasbi $^{2}$ \\ Program Studi S1 Adminitrasi Bisnis, Fakultas Komunikasi dan Bisnis, Universitas Telkom \\ aeniwidya12@gmail.comimanhasbi@telkomuniversity.ac.id ${ }^{2}$
}

\begin{abstract}
This research will discuss the effect of a green marketing program on purchasing decisions on Indomilk products by millennial generation. The purpose of this research is to determine the millennial generation responses to the green marketing program conducted by Indomilk, determine the purchasing decisions by the millennial generation on Indomilk products, and to determine the effect of green marketing programs on purchasing decisions on the influence of green marketing by millennial generation on Indomilk products, PT. INDOLAKTO.

The method used in this research is quantitative analysis with descriptive and causal research. This study uses simple linear regression analysis techniques and sampling techniques using purposive sampling techniques in which the samples in this study are millennials who have consumed Indomilk. The number of respondents in this study was 100 respondents. The results of this study partially, green marketing significantly influence purchasing decisions with a large effect of $51.7 \%$.

The conclusion of this research is the implementation of the green marketing program in Indomilk as a whole is included in a "Good" category and millenial generation responses to green marketing conducted by Indomilk tend to be positive, in the sense of word millenial generation supporting the greening program conducted by Indomilk. Millenial generation purchasing decision as a whole are included in a "Good" category, this generation assumes that Indomilk product can meet their needs and feel happy by buying Indomilk product, Indirectly participating in supporting in the green program that has been carried out by Indomilk.
\end{abstract}

Keywords: Green marketing, purchasing decision, indomilk, millenials.

Abstrak : Penelitian ini akan membahas mengenai pengaruh program green marketing terhadap keputusan pembelian pada produk Indomilk oleh generasi millenial. Tujuan dari penelitian ialah untuk mengetahui tanggapan generasi millenial terhadap program green marketing yang dilakukan oleh Indomilk, mengetahui keputusan pembelian oleh generasi millenial pada produk Indomilk, dan untuk mengetahui pengaruh program green marketing terhadap keputusan pembelian pengaruh green marketing oleh generasi millenial pada produk Indomilk, PT. INDOLAKTO.

Metode yang digunakan pada penelitian ini ialah analisis kuantitatif dengan jenis peneltian deskriptif dan kausal. Penelitian ini menggunakan teknik analisis regresi linear sederhana serta teknik pengambilan sampel menggunakan teknik purposive sampling yang dimana sampel pada pnelitian ini merupakan generasi millenial yang pernah mengkonsumsi Indomilk. Jumlah responden yang diambil sebanyak 100 responden. Hasil daripada penelitian ini secara parsial, green marketing berpengaruh terhadap keputusan pembelian secara signifikan dengan besar pengaruh $51,7 \%$.

Kesimpulan pada penelitian ini Pelaksanaan green marketing di Indomilk secara keseluruhan masuk kedalam kategori "Baik" dan tanggapan generasi millenial terhadap green marketing yang dilakukan oleh Indomilk cenderung positif, dalam arti kata generasi millenial mendukung program penghijauan yang dilakukan Indomilk. Keputusan pembelian oleh generasi millenial secara keseluruhan masuk kedalam kategori "Baik", generasi ini berasumsi bahwa produk Indomilk dapat memenuhi kebutuhannya dan merasa senang dengan membeli produk 
Indomilk, secara tidak langsung ikut serta dalam mendukung program hijau yang telah dilakukan Indomilk.

Kata kunci: Green marketing, keputusan pembelian, indomilk, generasi millenial

\section{A. PENDAHULUAN}

\section{Latar Belakang}

Persoalan sampah menjadi suatu tugas bagi pemerintah maupun masyarakat, khususnya di Indonesia. Dari banyaknya jenis sampah yang dihasilkan, terdapat 5 (lima) jenis sampah yang paling sering ditemukan, antara lain puntung rokok, kemasan makanan, kresek, styrofoam, dan sedotan plastik (Kompas.com, 2019) ${ }^{[1]}$.

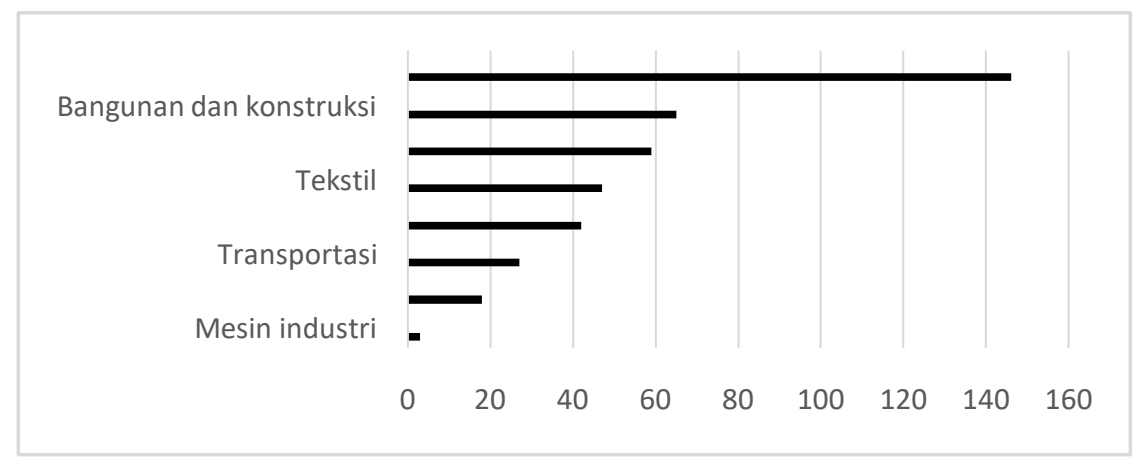

\section{Gambar 1. 1 Jenis Sampah Berdasarkan Persentase}

Sumber: Geyer, et al. $(2017)^{[2]}$

Indonesia produksi 64 juta ton per tahunnya, dimana angka tersebut cukup besar dan sekitar 3,2 juta ton sampah plastik dibuang dengan sengaja ke laut. Dilansir pada berita CNBC Indonesia, Indonesia adalah negara kedua yang menghasilkan sampah plastik dan dibuang ke laut (Adharsyah, 2019) ${ }^{[3]}$. Berikut merupakan data negara yang menyumbang sampah plastik. Indomilk menjadi salah satu penyumbang sampah plastik jenis kemasan makanan dan minuman, dikarenakan kemasan pada produk Indomilk masih menggunakan botol plastik pada Susu Cair Indomilk (SCI) serta karton Tetra Pak pada Pasteurized Liquid Milk dan UHT dan plastik sachet pada produk susu sachet kental manis Indomilk. Bahan karton Tetra Pak yang digunakan pada kemasan produk Indomilk (Pasteurized Liquid Milk dan UHT) memiliki lapisan kertas (74\%), aluminium(5\%), dan polietilen (21\%)yang dimana lapisan tersebut bisa didaur ulang. Indomilk ikut serta dalam mendukung program Go-Green, perusahaan ini pun melakukan kegiatan CSR dan sekaligus untuk mempromosikan produknya dalam mewujudkan visi mereka yaitu "Turut mercerdaskan anak bangsa". Indomilk, PT. INDOLAKTO masuk kedalam 69 perusahaan yang terdaftar sebagai industri hijau. Dalam daftar tersebut dibagi menjadi 2 tingkatan yaitu sebanyak 35 perusahaan berada pada level 4 dan 34 perusahaan berada pada level 5 (DetikFinance, 2013) ${ }^{[4]}$.

Keputusan pembelian yang dilakukan oleh konsumen melibatkan rasa kepercayaan diri atas keyakinannya terhadap suatu produk. Rasa percaya diri dapat menunjukkan tingkatan keyakinan pada suatu produk (Kotler \& Keller, 2009) ${ }^{[5]}$. Perusahaan mengharapkan upaya green marketing yang telah dilakukan mempengaruhi keputusan pembelian oleh konsumen serta dapat lebih peka lagi terhadap produk yang mendukung program hijau. Segmentasi pada produk Indomilk merupakan semua kalangan, mulai dari balita sampai orang dewasa. Dilansir pada berita marketeers.com, "Pada prinsipnya, strategi yang kami jalankan adalah mendekatkan diri pada konsumen, dalam hal ini adalah anak-anak. Di antaranya, kami menggelar kampanye promosi dan menggunakan karakter tokoh film anak, Boboiboy." Tutur Danang Prana 
Hadyoleksono, Brand Manager Indomilk. Hal tersebut tidak menutup kemungkinan generasi millenial turut mengkonsumsi produk Indomilk.

Berdasarkan pemaparan diatas, penulis terdorong untuk melakukan penelitian pada generasi meillenial dengan studi kasus pada produk Indomilk, PT. INDOLAKTO dengan judul " Pengaruh Program Green Marketing Terhadap Keputusan Pembelian Oleh Generasi Millenial (Studi Kasus Pada Produk Indomilk, PT.INDOLAKTO) ”

Identifikasi masalah

Berdasarkan yang peneliti jelaskan diatas, ada beberapa pertanyaan yang peneliti ajukan untuk menjadi bahasan dan untuk dijawab dalam penilitian ini:

1. Bagaimana tanggapan generasi millenial terhadap program green marketing yang dilakukan Indomilk, PT. INDOLAKTO?

2. Bagaimana keputusan pembelian oleh generasi millenial pada produk Indomilk, PT. INDOLAKTO?

3. Bagaimana pengaruh green marketing terhadap keputusan pembelian oleh generasi millenial pada produk Indomilk, PT. INDOLAKTO?

Tujuan

Berdasarkan pertanyaan yang telah diajukan oleh peneliti, berikut beberapa tujuan dalam penelitian ini:

1. Untuk mengetahui tanggapan generasi millenial terhadap program green marketing yang dilakukan Indomilk, PT. INDOLAKTO.

2. Untuk mengetahui keputusan pembelian oleh generasi millenial pada produk Indomilk, PT. INDOLAKTO.

3. Untuk mengetahui pengaruh green marketing terhadap keputusan pembelian oleh generasi millenial pada produk Indomilk, PT. INDOLAKTO.

\section{B. TINJAUAN MASALAH}

Pemasaran

Pemasaran adalah bentuk dari kegiatan yang merumuskan serta pemenuhan kebutuhan manusia maupun sosial. Adapun pengertian lain dari pemasaran sebuahpemenuhan dari segala kebutuhan dengan mendapatkan laba. Menurut American Marketing Association (AMA), pemasaran adalah serangkaian proses untuk mengkomunikasikan, memberikan nilai kepada pelanggan untuk mengatur hubungan dengan pelanggan dengan cara yang menguntungkan bagi pemegang kepentingan dan organisasi, dan menciptakan sesuatu(Kotler \& Keller, 2009) ${ }^{[5]}$.

\section{Green Marketing}

Green Marketing merupakan kegiatan yang memasarkan produk yang ramah lingkungan dengan memasukkan beberapa kegiatan seperti perubahan proses, memodifikasi produk, kemasan, strategi pemasaran, serta meningkatkan kesadaran pemasaran. Singh dalam Paysal $(2016)^{[6]}$ mengemukakan bahwa elemen yang terdapat pada bauran pemasaran konvensional meliputi 4P yaitu (Price, Product, Place, Promotion) dapat dilakukan dengan metode strategi pemasaran hijau atau greenmarketing strategy dan dengan cara yang inovatif dari bauran pemasaran dan mengidentifikasi perbedaan tentang bagaimana unsur 4P yang terlibat dalam strategi pemasaran, yaitu green product, green promotion, green place, green price.

Keputusan Pembelian 
Proses psikologi dalam memahami bagaimana konsumen membuat keputusan pembelian merupakan peranan yang sangat penting. Perusahaan perlu memahami proses keputusan pembelian oleh konsumen secara keseluruhan, mulai dari menggunakan, memilih, bahkan menyingkirkan produk yang tidak disukai, konsumen melewati setidaknya 5 (lima) tahapan dalam proses keputusan pembelian, yaitu pengenalan masalah, pencarian informasi, evalusi alternatif, keputusan pembelian, dan perilaku pascapembelian (Kotler \& Keller, 2016) ${ }^{[7]}$.

\section{METODOLOGI PENELITIAN}

Metode yang digunakan ialah kuantitatif serta jenis penelitian deskriptif dan kausal. Penelitian dibuat untuk melihat hubungan antar varaibel dan memaparkan hasil penelitian. Dalam penelitian ini peneliti akan menjelaskanbagaimana hubungan pada masing variabel dengan menggunakan perhitungan statistik, kuesioner digunakan sebagai instrumen penelitian, dan penelitian dibuat untuk menguji hipotesis yang telah dibuat oleh peneliti. Teknik pengambilan sampel menggunakannon-probality sampling dan purposive sampling. Teknik analisis yang digunakan pada penelitian ini merupakan teknik analisis regresi linear sederhana.Populasi penelitian ini merupakan generasi millenial sebagai konsumen kampus yaitu mahasiswa yang pernah mengkonsumsi Indomilk. Adapun sampel yang diambil sebanyak 100 responden.

\section{HASIL DAN PEMBAHASAN}

Analisis Deskriptif

Tabel 4.1 Tanggapan Responden Terkait Varibel Green Marketing (X)

\begin{tabular}{|c|l|c|c|}
\hline No & \multicolumn{1}{|c|}{ Dimensi } & $\begin{array}{c}\text { Rata-rata skor } \\
\text { total }\end{array}$ & $\begin{array}{c}\text { Rata-rata (Dalam } \\
\text { persentase) }\end{array}$ \\
\hline $\mathbf{1}$ & Green product & 424,7 & $84,95 \%$ \\
\hline $\mathbf{2}$ & Greeen price & 35,7 & $71,53 \%$ \\
\hline $\mathbf{3}$ & Green place & 393,2 & $78,65 \%$ \\
\hline $\mathbf{4}$ & Green promotion & 374 & $74,8 \%$ \\
\hline & $\quad$ Total & $1.549,6$ & 77,485 \\
\hline
\end{tabular}

Sumber: hasil olahan data peneliti, 2020

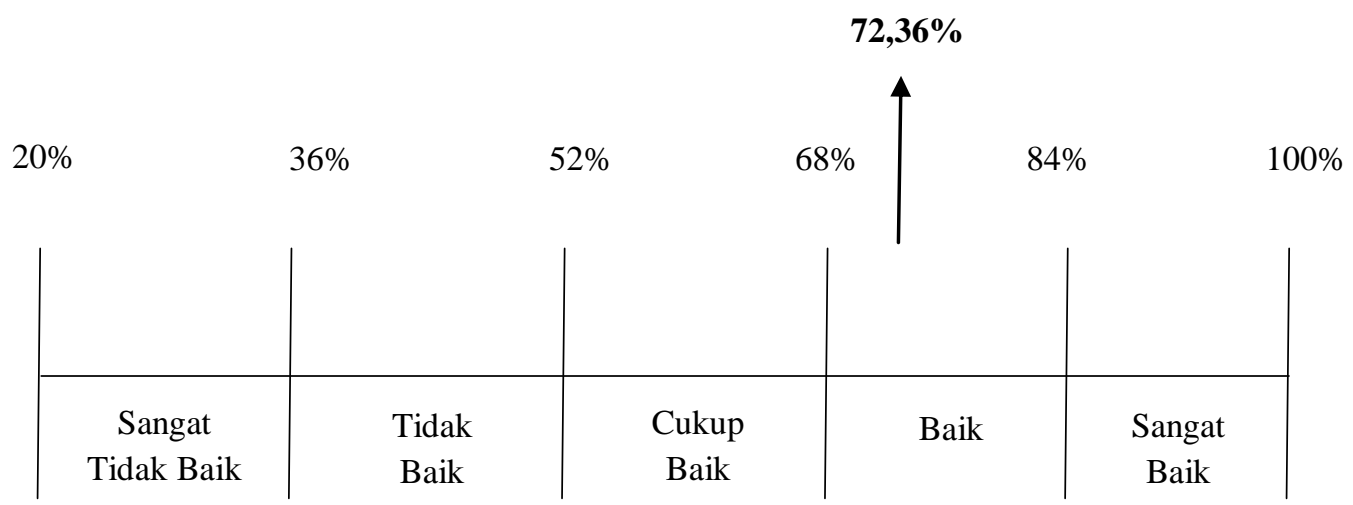

Gambar 4.1 Garis Kontinum Tanggapan Responden Terkait Variabel Keputusan Pembelian (Y) Sumber: Hasil Data Olahan Peneliti, 2020 


\section{Uji Asumsi Klasik}

\section{a. Uji Normalitas}

Berdasarkan gambar dan kriteria pengambilan keputusan, data yang disajikan terdistribusi dengan normal. Hal ini dapat diartikan bahwa model tersebut dapat digunakan untuk mengukur variabel keputusan pembelian berdasarkan masukan variabel independen.

\section{b. Uji Heterokedastisitas}

Berdasarkan hasil olahan SPSS versi 22, dapat dilihat bahwa diagram pencar tidak membentuk pola, dengan kata lain tidak mengalami gangguan heterokedastisitas.

Analisis Regresi Linear Sederhana

Berdasarkan hasil olahan data, berikut persamaan yang diperoleh:

$$
\begin{gathered}
\mathrm{Y}=\mathrm{a}+\mathrm{bX} \\
\mathrm{Y}=-8,149+1,225 \mathrm{X} \\
\mathrm{Y}=-8,149+1,225(100) \\
\mathrm{Y}=-8,149+12,25 \\
\mathrm{Y}=4,101
\end{gathered}
$$

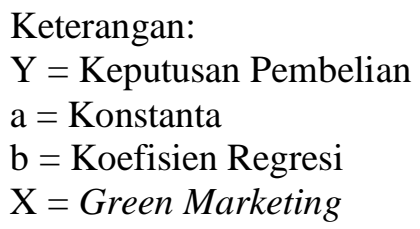

Persamaan tersebut dapat diartikan bahwa nilai konstanta pada green marketing sebesar 8,149. Nilai koefisien regresi sebesar 1,225 bersifat positif dan memiliki hubungan searah terhadap variabel keputusan pembelian. Apabila pada variabel green marketing dikalikan 100 satuan, maka setiap pertambahan satuan pada green marketing akan berpengaruh terhadap meningkatnya keputusan pembelian sebesar 4,101. Berdasarkan penjelasan dan perhitungan diatas, peneliti berasumsi bahwa ada atau tidak adanya program green marketing yang dilakukan oleh Indomilk, keputusan pembelian tetap terjadi.

\section{Uji Hipotesis (uji t)}

Hasil olahan data diketahui nilai $\mathrm{t}$ green marketing ialah 10,249 yang dimana nilai tersebut lebih besar dari nilai $t_{\text {tabel }}$ sebesar 1,66 $(10,249>1,66)$ dengan nilai signifikansi lebih kecil dari $0,05(0,000<0,05)$. Demikian dapat disimpulkan bahwa $H_{0}$ ditolak dan $H_{1}$ diterima, hal ini dikarenakan $t_{\text {hitung }}$ lebih besar dari $t_{\text {tabel }}$ dan nilai signifikansi lebih kecil dari 0,05 . Maka green marketing memiliki pengaruh signifikan terhadap keputusan pembelian.

\section{E. KESIMPULAN DAN SARAN}

Kesimpulan

Berdasarkan hasil analisis dan pembahasan yang telah dijabarkan mengenai pengaruh program green marketing terhadap keputusan pembelian oleh generasi millenial (studi kasus pada produk Indomilk, PT. INDOLAKTO), maka diperoleh beberapa kesimpulan, berikut adalah beberapa kesimpulan yang diperoleh: 
1. Pelaksanaan green marketing di Indomilk secara keseluruhan masuk kedalam kategori "Baik" dan tanggapan generasi millenial terhadap green marketing yang dilakukan oleh Indomilk cenderung positif, dalam arti kata generasi millenial mendukung program penghijauan yang dilakukan Indomilk.

2. Keputusan pembelian oleh generasi millenial secara keseluruhan masuk kedalam kategori "Baik", generasi ini berasumsi bahwa produk Indomilk dapat memenuhi kebutuhannya dan merasa senang dengan membeli produk Indomilk, secara tidak langsung ikut serta dalam mendukung program hijau yang telah dilakukan Indomilk.

3. Berdasarkan variabel yang telah dianalisis, diketahui bahwa variabel independen (green marketing) berpengaruh signifikan terhadap variabel dependen (keputusan pembelian). Besarnya pengaruh green marketing terhadap keputusan pembelian yang diperoleh sebesar $51,7 \%$ dan sekitar $48,3 \%$ lainnya dipengaruhi oleh faktor yang tidak diteliti pada penelitian ini.

Saran selanjutnya.

Terdapat beberapa saran dengan harapkan dapat bermanfaat kepada objek dan peneliti

1. Saran Bagi Objek

b. Peneliti menyarankan untuk lebih peduli terhadap persoalan sampah yang menimbulkan banyak pengaruh negatif terhadap lingkungan.

c. Terus mendukung dan turut serta dalam program yang penghijauan.

2. Saran Bagi Perusahaan

a. Mengurangi kemasan yang berbahan dasar plastik guna upaya meminimalisir efek yang ditimbulkan oleh plastik terhadap lingkungan

b. Menerapkan program R lainnya, seperti Reuse, Rethink, Replace, Refuse, Repair, dsb dalam menjalankan bisnis.

c. Lebih gencar dalam mengkomunikasikan program hijau yang dilakukan kepada masyarakat umum.

3. Saran Bagi Peneliti Selanjutnya

a. Sangat memungkinkan apabila peneliti berikutnya dapat menambahkan variabel lainnya kedalam penelitiannya.

b. Disarankan untuk mencari ruang lingkup dan objek yang berbeda.

\section{F. DAFTAR PUSTAKA}

Kompas.com. (2019, Februari). 5 Jenis Sampah Terbanyak di Bumi, dari Puntung Rokok hingga Styrofoam. Retrieved from kompas.com: https://sains.kompas.com/read/2019/02/21/200000223/5-jenis-sampah-terbanyak-dibumi-dari-puntung-rokok-hingga-styrofoam?page=all

Geyer, R., Jambeck, J. R., \& Law, K. L. (2017). Production, use, and fate of all plastics ever made. Science Advances, Vol. 3, no. 7.

Adharsyah, T. (2019, Juli). Sebegini Parah Ternyata Masalah Sampah Plastik di Indonesia. Retrieved from CNBC Indonesia: https://www.cnbcindonesia.com/lifestyle/20190721140139-33-86420/sebegini-parahternyata-masalah-sampah-plastik-di-indonesia

DetikFinance. (2013, November). Ini Dia 69 Perusahaan yang Masuk Daftar Industri Hijau. Retrieved from DetikFinance: https://finance.detik.com/industri/d-2423697/ini-dia-69perusahaan-yang-masuk-daftar-industri-hijau

Kotler, P., \& Keller, K. L. (2009). Manajemen Pemasaran, Edisi 13, Jilid 1. Jakarta: Erlangga.

Paysal, S. A. (2016). Pengaruh Green Marketing Terhadap Keputusan Pembelian Pada Produk Nike di Bandung Tahun 2016 (Vol.2, No.3 December 2016). 
Singh, P. (2010, July). Green Marketing: Opportunity for Innovation and Sustainable Development

Kotler, P., \& Keller, K. L. (2016). Marketing Edition (Global Edition). England: Pearson Education 